\title{
Breast Cancer Pathologic Distant Metastasis TNM Finding v8
}

National Cancer Institute

\section{Source}

National Cancer Institute. Breast Cancer Pathologic Distant Metastasis TNM Finding v8. NCI Thesaurus. Code C139409.

A pathologic finding about one or more characteristics of breast cancer, following the rules of the TNM AJCC V8 classification system as they pertain to distant metastases. 